\title{
THE FACTOR STRUCTURE OF SIX SALUTOGENIC CONSTRUCTS
}

\author{
MARITA BREED \\ FRANS CILLIERS \\ DELÉNE VISSER \\ Department of Industrial \& Organisational Psychology \\ Unisa
}

\begin{abstract}
The aim of this research was to investigate the factor structure of six salutogenic constructs, namely sense of coherence, hardiness, learned resourcefulness, potency, internal locus of control and self-efficacy. Measurement with a sample of 935 part-time students did not fit the conceptualisation of salutogenesis. A different factor structure for Whites versus Others occurred. For Whites, all six constructs more or less contributed towards the general salutogenic factor and for Others all but learned resourcefulness contributed. For Whites, salutogenesis consisted of two clear dimensions (a global positive orientation; specific behavioural skills) and for Others one dimension (an optimistic life view). Confirmatory factor analysis performed on the data for both groups, indicated a weak fit. It was recommended that salutogenesis be further explored within an overall personality theory.
\end{abstract}

\section{OPSOMMING}

Die doel van hierdie navorsing was om die faktorstruktuur van ses salutogeniese konstrukte te ondersoek, naamlik sin vir koherensie, gehardheid, aangeleerde vindingrykheid, potensie, interne lokus van beheer en selfgenoegsaamheid. Meting met ' $\mathrm{n}$ steekproef van 935 deeltydse studente het nie ' $\mathrm{n}$ passing getoon met die konseptualisering van salutogenese nie. 'n Eiesoortige faktorstruktuur vir Wit studente versus Ander studente het voorgekom. Vir Wittes, het al ses die konstrukte meer of minder bygedra tot die algemene salutugeniese faktor en vir Andere het almal behalwe aangeleerde vindingrykheid bygedra. Vir Wittes bestaan salutogenese uit twee duidelike dimensies ('n globale positiewe lewensorientasie; spesifieke gedrags vaardighede) en vir Andere uit een dimensie ('n optimistiese lewensbeskouing). Bevestigende faktor ontleding uitgevoer op die data van beide groepe, het ' $\mathrm{n}$ swak passing getoon. Daar is aanbeveel dat salutogenese verder ondersoek word binne 'n oorkoepelende persoonlikheidsteorie.

Over the past decade the focus on individual salutogenic functioning (Strümpfer, 1990), has spread from the field of growth psychology to include its application in the work environment (see Basson \& Rothmann, 2001; Cilliers \& Kossuth, 2002; 2004; Cilliers, Viviers \& Marais, 1998; Jackson, 2004; Rothmann, 2002; Storm, 2002). This facilitated a clearer idea of the guidelines for the conceptualisation and operationalisation of psychological growth and wellness of employees and managers, which are known to play a significant role in their coping with environmental and organisational demands, such as change and transformation.

The salutogenic paradigm and its constructs developed from various personality theories emphasising personality growth, wellness and optimal psychological functioning (Antonovsky, 1987; Strümpfer, 1995). From 2000 onwards, many new positive psychology constructs were added to this body of knowledge (Carr, 2004; Frederickson, 2001; Snyder \& Lopez, 2002). Positive psychology is defined as the scientific study of ordinary, positive, subjective human strengths, virtues, experiences and functioning (Seligman \& Csikszentmihalyi, 2000; Sheldon \& King, 2001). In this context, substantial South African research has been reported that focussed on salutogenesis (Strümpfer, 1990), fortigenesis (the origin of strengths - Fouché, 1999; Strümpfer, 1995) and psychofortology (Coetzee \& Cilliers, 2001).

Positive psychology includes many behavioural constructs such as self-actualisation, sense of coherence, hardiness, potency, selfefficacy, learned resourcefulness, internal locus of control (Strümpfer, 1990), coping (Somerfield \& McCrae, 2000), wellbeing (Lyubomirsky, 2001), creativity and flow (Nakamura \& Csikszentmihalyi, 2001; Simonton, 2000), resilience (Masten, 2001), emotional intelligence (Lopez \& Snyder, 2003), engagement (Rothmann, 2002), authentic (Seligman, 2003) happiness (Diener, 2000), humour (Fredrickson, 2001), positive affect (Folkman \& Moskowitz, 2000), courage, gratitude (Lopez \& Snyder, 2003), faith and optimism (Peterson, 2000; Schneider, 2001). In the last six years many of these constructs have been measured and applied in South African organisations, specifically in employee counselling, and individual and organisational development (Breed, 1997; Cilliers, 2001; 2002; Cilliers \& Coetzee, 2003; Cilliers \& Kossuth, 2002; 2004; Cilliers, Viviers \& Marais, 1998; Jackson, 2004; Johnson, 1993; Kossuth \& Cilliers, 2002; Linley \& Joseph, 2004; Storm, 2002; Viviers, 1996; Wissing \& Van Eeden, 2002).

The operationalisation of these constructs is used increasingly in performance management and employee development, as a way of explaining the way in which individuals function and develop, cope with change and transformation, and adapt to the new world of work and its demands (Kossuth, 1998). Although most of the existing instruments for the measurement of these constructs (as suggested for example by Lopez \& Snyder, 2003; Strümpfer, 1990), exhibit the necessary psychometric qualities of reliability and validity, it is not clear whether their operationalisation confirms the relatively newly formulated underlying theoretical models. This poses a challenge to I/O psychologists and HR practitioners to clear up this uncertainty for the purposes of future research and practice (Wissing, 2000), and to explicate this new paradigm and its constructs further (Strümpfer \& Wissing, 1998). This is especially pertinent in the unique South African work environment which is characterised by scarcity in job opportunities as well as human resources suffering from high levels of stress, burnout and depression (see Strümpfer, 1990; 1995; Wissing \& Van Eeden, 1994; 1997a; 1997b).

Antonovsky (1987) endorsed the notion that work has a significant role to play in shaping a person's salutogenic functioning, and specifically his/her sense of coherence. A working environment which is predictable, manageable and where the employee can participate in decision making and has a voice in regulating his/her work enhances the sense of coherence of the worker because work is experienced as meaningful. Strümpfer (1995) supports Antonovsky's (1987) finding that specific work experiences strengthen salutogenic functioning. Strümpfer and Wissing (1998) cite examples of organisational behaviour such as job involvement, organisational commitment, organisational change and job satisfaction which have been found to strengthen the sense of coherence. 
Research on salutogenesis has received special attention in South Africa since 1990. Salutogenic thinking explains the extent to which an individual is able to cope with stressful circumstances which facilitates more optimal performance in various spheres of life (Aspinwall \& Staudinger, 2003; Keyes \& Haidt, 2003; Strümpfer, 1990). Both international and South African research results increasingly support the relationship between salutogenic (Antonovsky, 1979, 1984a; 1984b) and fortigenic functioning (Strümpfer, 1995), and various individual behavioural constructs as well as work performance. Strümpfer and Wissing (1998) gave a summary of such results using sense of coherence, as the most widely recognised salutogenic construct (Antonovsky, 1987). Examples of behavioural constructs being correlated with sense of coherence within the field of work are stress, absence of burnout, self-esteem, life satisfaction, extroversion, independence, conscientiousness, agreeableness, powerlessness and social support (Barnard, 2001; Basson \& Rothmann, 2001; Boyle, Grap, Younger \& Thornby, 1991; Brooks, 1992). Examples relating to the individual's organisational behaviour are job satisfaction (Strümpfer, 1998), job involvement, organisational commitment, empowerment, organisational change (Cilliers \& Kossuth, 2002; 2004; Kossuth \& Cilliers, 2002; Lochner, 2000; Motshele, 2001; Naudé, 1999; Viviers, 1996).

\section{Salutogenic functioning}

Salutogenesis (Antonovsky, 1979) focuses on the origins of health and wellness (Latin salus = health; Greek genesis = origins). Instead of studying abnormal behaviour, this paradigm focusses on locating and developing personal and social resources and adaptive tendencies which result in effective coping behaviour and growth (Breed, 1997). Strümpfer (1990) suggested that there are six significant salutogenic strengths, namely, the sense of coherence, hardiness, learned resourcefulness, potency, internal locus of control and selfefficacy.

\section{Sense of coherence (SOC)}

SOC is defined as a global orientation that expresses the extent to which one has a pervasive, enduring, though dynamic feeling of coherence manifesting in the following behavioural experiences or dimensions (Antonovsky, 1984a; 1987). (1) The stimuli deriving from one's internal and external environments in the course of living are structured, predictable and explicable. This is called comprehensibility, where one makes sense of the stimuli in the environment. (2) The belief that resources are available to one to meet the demands posed by these stimuli. This is called manageability, where one is able to cope with the demands of the environment. (3) The belief that these demands are challenges worthy of investment and engagement. This is called meaningfulness, where one is able to identify emotionally and commit effort to handling these demands. Antonovsky (1979) noted that the strength of the SOC is connected to a variety of coping mechanisms which he referred to as generalised resistance resources (GRRs), defined as any characteristic of the individual, the group, or the environment that can facilitate effective tension management. He identified these as artifactual which include material resources (money, wealth), cognitive-emotional-intrapersonal and emotional (knowledge, intelligence, ego identity), valuative-attitudinal-rationality, flexibility and farsightedness; interpersonal-relational (social support systems) and macro-socio-cultural (cultural norms and rules which control societal and organisational behaviour). Antonovsky (1987) supported the notion that work has a significant role to play in shaping a person's SOC. A work environment which is predictable, manageable and where the employee can participate in decision making and has a voice in regulating his/her work, enhances the SOC of the worker because work is meaningful. Strümpfer supported Antonovsky's (1987) thought that work experiences strengthen the SOC. He stated, "all else being equal, I can hardly see where such an orientation to work as outlined above can lead, other than to productive performance, recognition, reward, and promotion. In turn, these experiences would become workrelated GRRs that will strengthen the sense of coherence further" (Strümpfer, 1990:270).

\section{Hardiness (HAR)}

HAR is defined as a constellation of personality characteristics that function as a moderator and resistance resource in the encounter with stressful life events (Kobasa, 1979a; 1979b; Kobasa, Maddi \& Kahn, 1982). Kobasa (1982) identified three dimensions, namely, commitment, control and challenge. Commitment (versus alienation) is a belief in the truth, importance and value of what one is and what one is doing. It is also the tendency to involve oneself actively in a number of situations in life, such as work, family, friendship and social organisations. Control (versus powerlessness) is a tendency to believe and act as if, by and large, one can influence the events of one's life through what one imagines, says or does, with an emphasis on personal responsibility. According to Strümpfer (1990), this component partly overlaps with internal-external locus of control. Challenge (versus threat) is an expectation that change, rather than stability, is the norm in life and that change will present one with opportunities and incentives for personal development. Persons high in hardiness easily commit themselves to what they are doing (rather than feeling alienated), generally believe that they can at least partially control events (rather than feeling powerless) and regard change to be a normal challenge or impetus to development (rather than a threat) (see Kobasa, Maddi \& Kahn, 1982; Kobasa, Maddi, Pucetti \& Zola, 1985; Kobasa, Maddi \& Zola, 1985; Kobasa \& Puccetti, 1983; Lambert \& Lambert, 1987).

\section{Learned resourcefulness $(L R)$}

LR is defined as an acquired repertoire of (mostly cognitive) behavioural skills according to which one self-regulates internal responses (such as cognition, emotions, pain) that interfere with the smooth execution of a desired behaviour (Rosenbaum, 1989; 1990; Rosenbaum \& Jaffe, 1983). LR is not a personality characteristic, but rather a set of complex behaviours that is in constant interaction with one's physical and social environment, and evoked by many situations one uses when confronted by situations that call for self-control and self-regulation. It also provides the basis for further learning (Rosenbaum \& Palmon, 1984).

\section{Potency (POT)}

POT is defined as the enduring confidence in one's own capacities as well as confidence in and commitment to one's social environment, which is perceived as being characterised by a basically meaningful, predictable order and by a reliable and just distribution of rewards (Ben-Sira, 1985). POT is therefore a stress-buffering mechanism (Ben-Sira, 1985) which will limit the homeostasis-disturbing impact of an occasional failure in meeting a demand because of resource inadequacy. This implies that one has enduring confidence in one's own capacity as well as confidence in and commitment to the social environment, which is perceived as being characterised by a basically meaningful and predictable order and by a reliable and just distribution of rewards. Ben-Sira (1989) distinguished two stages in this coping process, namely, the primary stage of responding to a demand upon confrontation with it, and the secondary stage of restoring homeostasis if coping in the initial stage was inadequate. Moreover, there has to be a homeostasis-stabilising mechanism over and above the normal resources of individuals that is sufficiently powerful to moderate the impact of inadequate coping, hence preventing occasional disturbances of emotional homeostasis from deteriorating into stress (Ben-Sira, 1989). 
Internal locus of control (ILOC)

ILOC is defined as the extent to which one perceives that one has control over a given situation (Rotter, 1966; Rotter, Seemand \& Liverant, 1962). Such individuals feel in control, empowered and masterful, see a relationship between own behaviour and outcomes, attribute the cause of events to the self and therefore experience less stress. Thus, one acquires large amounts and diverse kinds of information, perceives own skill and judgement as a means to solving problems (Garson \& Stanwyck, 1997), attends to own self-development, shows initiative, develops constructive relationships, is participative, enterprising and achieves results (Foley \& Clifton, 1990; Payne \& Manning, 1988). An external locus of control refers to feeling out of control, to see no relationship between own behaviour and events, to attribute the cause of events to the environment, others and fate, and to feel anxious, frustrated and helpless. Work-wise, one perceives performance as dependent on incentives, and believes that the withdrawal of these will lead to a loss in production (Erwee \& Pottas, 1982). The differentiation between the internal and external positions lies in the experience of freedom (Antonovsky, 1991), attribution and cognitive performance (Rotter, 1966).

Self-efficacy (SE)

SE is defined as the belief that one has the capabilities to exercise control over events that affect one's life, to mobilise the motivational and cognitive resources, and courses of action needed to meet given situation-demands (Bandura, 1977; 1982; 1989; 1997; Wood \& Bandura, 1989). One sets high, challenging and achievable goals, shows commitment and exercises choice and control over events in one's life, which stimulates more success (Gist \& Mitchell, 1992; Kirsch, 1986). A responsive, encouraging and rewarding environment, valuing aspirations, engagement and accomplishments, stimulates self-efficacy further and improves performance (Bandura, 1997; Barling \& Beattie, 1983; Feltz, 1982; Hackett \& Betz, 1981; Lee, 1988; Taylor, Locke, Lee \& Gist, 1984).

The salutogenic profile

From the above, salutogenic functioning is seen as consisting of the following behaviour (also see Breed, 1997; Viviers \& Cilliers, 1999; Viviers, 1999)). On the cognitive level, the individual is able to view stimuli from the environment in a positive and constructive manner, and to use the information towards effective decision making. On the affective level, the individual functions with self-awareness, confidence, self-fulfilment, viewing stimuli as meaningful and acting with commitment towards life in a mature manner. On the motivational level, the individual has intrinsic motivation, perceives stimuli as a challenge which directs his/her energy to cope, solve problems and achieve results. The interpersonal characteristics entail the capacity to form meaningful and rewarding relationships with others at work and in society.

For the present research it was decided to focus on the above six salutogenic strengths as identified by Strümpfer (1990), and to investigate whether they form a salutogenic factor when measured in a single study. If it can shown that a combination of all of these constructs contribute towards the salutogenic profile that defines salutogenic functioning, this knowledge could continue towards a better understanding of the nature of a general salutogenic construct. The research question being investigated was therefore whether the operationalisation of the six salutogenic constructs fit the theoretical and conceptual views of salutogenic functioning.

\section{RESEARCH DESIGN}

\section{Participants}

A sample of convenience consisting of 935 part-time students, registered for their second year of Industrial Psychology at a distance education university, was obtained. All the students that were registered during 1993 for this course were invited to participate, and a total of $47 \%$ responded by submitting completed questionnaires. It appears reasonable to assume that the population of students that are studying at the distance teaching university, represent a broad spectrum of working adults throughout South Africa.

To test the possibility of differences between groups, the sample was divided into two groups based on the various South African population groups. The White group consisted of 732 participants ( $78 \%$ of the sample), whereas the Black, Coloured and Indian groups combined, hereafter referred to as Other Groups, consisted of 203 participants (22\% of the sample). The sample size of 203 in the Other groups was considered as inadequate to allow comparisons between all four groups by subdividing the sample further.

The respondents in the White group indicated that $81 \%$ of them had lived and worked in an urban environment for most of their lives, whereas the rest of the group lived in rural areas. For the Other groups, the urbanised percentage was also $81 \%$. The distributions with respect to age and marital status for the two samples are given in Table 1.

\section{TABLE 1}

DISTRIBUTIONS OF AGE AND MARITAL STATUS OF THE TWO SAMPLES

\begin{tabular}{lcc}
\hline Age & White group & Other groups \\
\hline Younger than 20 & $7,5 \%$ & $0,5 \%$ \\
$20-30$ & $54,4 \%$ & $42,9 \%$ \\
$31-40$ & $27,9 \%$ & $43,3 \%$ \\
$41-50$ & $9,0 \%$ & $9,9 \%$ \\
Older than 50 & $1,2 \%$ & $1,0 \%$ \\
\hline Marital status & White group & Other groups \\
\hline Married & $44,5 \%$ & $46,3 \%$ \\
Divorced & $6,0 \%$ & $0 \%$ \\
Single & $49,2 \%$ & $52,2 \%$ \\
Widowed & $0,3 \%$ & $1,0 \%$ \\
\hline
\end{tabular}

\section{Measuring instruments}

Six existing measuring instruments were chosen to assess the six salutogenic constructs as discussed above.

Sense of Coherence (SOC)

The Orientation to Life Questionnaire developed by Antonovsky (1987) was used to measure SOC, as defined above. It consists of 29 items with a 7-point Likert scale response format that is anchored at the two poles of the scales. Thirteen of the items are negatively worded to counteract response styles and these items have to be reverse coded. A high score is indicative of a strong sense of coherence, whereas a low score represents a weak sense of coherence. Antonovsky $(1979 ; 1987)$ originally proposed three subscales for the questionnaire. Comprehensibility (COMP) is measured by 11 items, meaningfulness (MEAN) in 8 items and manageability (MANA) by 10 items. However, empirical verification of the three-factor structure of sense of coherence as initially conceptualised by Antonovsky (1979), could not be found. He later conceded that sense of coherence should be regarded as a unidimensional construct (Antonovsky, 1987). This viewpoint was also supported by Frenz, Carey and Jorgensen (1993) who obtained intercorrelations of 0,71 or higher between the three subscales. Use of total scores on the SOC questionnaire, rather than separate scores on the three subscales, are therefore indicated. 
Evidence of satisfactory reliability has been found in several studies. Test-retest reliabilities of 0,92 over one week and 0,93 over two weeks were reported by Frenz (1990). Antonovsky (1993a; 1993b) summarised the results of test-retest reliability estimates obtained in various studies. The coefficients varied between 0,41 and 0,97 . With respect to internal consistency reliability, Antonovsky (1987) reported alpha coefficients varying between 0,84 and 0,93 for the total scale. In another sample of 1 333 patients, internal consistency reliabilities of $0,87,0,90$ and 0,80 for the three subscales and 0,95 for the total questionnaire were found. Kalimo and Vuori (1990) and Dahlin, Cederblad, Antonovsky and Hagnell (1990) reported reliabilities of 0,93 and 0,89 for the total questionnaire respectively. Further evidence of the substantial internal consistency reliability of the SOC questionnaire was demonstrated when Antonovsky (1993a; 1993b) summarised the results of 29 studies conducted in various cultural and language groups globally. The alpha coefficients that he reported varied from 0,85 to 0,91 . The SOC questionnaire has also been used in South Africa where it yielded similarly acceptable reliability (Danana, 1989; Strümpfer \& Wissing, 1998).

Several studies attempting to validate the SOC questionnaire have been cited in the literature. For instance, the construct validity of the SOC questionnaire was investigated when Flannery, Perry, Penk and Flannery (1994) found that it correlated with stress, psychological distress and the Beck Depression Inventory. Further evidence of convergent validity was found when Bernstein and Carmel (1987) obtained a negative correlation between anxiety and SOC and when Antonovsky and Sagy (1990) established that SOC correlated negatively with fear. In terms of criterion validity, concurrent validity was evident in studies in which the SOC questionnaire correlated positively with health variables and negatively with negative health variables. In view of the above findings, it was argued that the SOC questionnaire meets the psychometric requirements for it to be used as a measure in the present study.

\section{Hardiness (HAR)}

The latest version of The Personality Hardiness Questionnaire, as originally developed by Kobasa (1979a; 1979b), was selected to measure hardiness. It contains 50 positively and negatively scaled items with a four-point Likert scale as its response format. The items are scored so that high scores indicate a high degree of hardiness. Commitment (COMM) is measured by 16 items, control (CONT) by 17 items and challenge (CHAL) by 17 items. Although there was evidence that the three dimensions are relatively independent of one another (Funk, 1992), it was decided to rely on the empirical evidence obtained in the present study to indicate whether total hardiness scores should be used to provide a measure of overall hardiness, or whether the use of subscales are more appropriate.

Evidence with regards to reliability and validity evidence of the version used in the present study is scant. Parkes and Rendall (1988) nevertheless obtained satisfactory test-retest reliability for the PHQ. In another study Funk (1992) reported a test-retest reliability of 0,60 over a period of two weeks. The decision to make use of total hardiness scores only, was vindicated by the high intercorrelations between the subscales that Parkes and Rendall (1988) obtained. For instance, they found a correlation of 0,78 between the Commitment and Control subscales.

Evidence of the convergent validity of the PHQ was found when a correlation of 0.89 was obtained between the PHQ and another hardiness scale (Campbell, Amerikaner, Swank \& Vincent, 1989). Despite the fact that they argued that hardiness and neuroticism are separate constructs, Wiebe and Williams (1992) obtained a high correlation between these variables. With respect to the criterion validity of the PHQ, Williams, Wiebe and Smith (1992) reported that the Commitment and Control scales were related to health and sickness variables, but that the Challenge subscale was not related to these variables.
Learned resourcefulness (LR)

The Self-control Schedule developed by Rosenbaum (1980) was used to measure the learned resourcefulness variable as defined above. The schedule consists of 36 items that were responded to on a six-point Likert scale. Total scores may be calculated after the negatively worded items have been reflected to yield general learned resourcefulness scores. Behaviour that is characteristic of learned resourcefulness is manifested by a high score on the questionnaire.

Rosenbaum (1980) reported internal consistency reliabilities for the SCS that ranged from 0,78 to 0,84 . Redden, Tucker and Young (1983) obtained an alpha coefficient of 0,82 for a large sample of American students. In a South African study by Edwards and Riordan (1994), alpha coefficients of 0,52 and 0,82 were found for Black and White university students respectively. It appears that the reliability of the questionnaire has been established for Whites, but not for Blacks.

Evidence for the convergent validity of the SCS was obtained when Rosenbaum (1980) obtained a correlation of 0,40 between internal locus of control, as measured by the Rotter scale and the SCS. Furthermore, the SCS correlated negatively with the Irrational Beliefs Test of Jones (1996) and Taylor's Manifest Anxiety Scale. In a later study, Rosenbaum and Ben-Ari (1985) established that the SCS correlated positively with task orientation as well as with self-evaluation.

\section{Potency (POT)}

The Potency Questionnaire developed by Ben-Sira (1985) was used to measure the potency construct as defined above. The Potency Questionnaire has 19 items for which a six-point Likert scale is used. It measures respondents' self-confidence, their perceived ability to master stressful situations by themselves, their general feeling of alienation, their perception of their standing in the social structure, and their ability to regain homeostasis after coping has failed.

Negatively worded items have to be reflected before total scores on the Potency Questionnaire are calculated. High scores indicate high levels of general potency. Ben-Sira (1985) used the least-spaceanalytic technique to explore the coping-stress-sickness domain, but no other studies have investigated the psychometric properties of the questionnaire. Validity and reliability information is therefore not available, but the questionnaire has an acceptable level of face validity (Antonovsky, 1987; Strümpher, 1990).

\section{Internal Locus of Control (LOC)}

The Locus of Control Questionnaire developed by Rotter (1966) was used in the present study to measure internal/external locus of control as defined above. This is a 29 -item forced choice questionnaire that measures individual beliefs regarding expectations on how rewards are controlled. Six of the 29 items do not measure locus of control - they were included to disguise the purpose of the questionnaire, and are disregarded in the administration. Every item consists of two statements and respondents had to choose which statement best represented their personal opinions. One of the statements expresses the opinion that the consequences of behaviour (success or failure) are the result of one's own behaviour (internal locus of control), whereas the other statement indicates that consequences may be attributed to external influences beyond the control of the respondent. In this study the questionnaire was scored so that beliefs typifying an internal locus of control resulted in high scores on the questionnaire, whereas low scores represented an external locus of control. The LOC questionnaire has subsequently been criticised for the fact that external locus of control expectations were too often attributed to luck, fatalism, or external control agents, rather than to significant others (Lefcourt, 1982).

The Rotter LOC questionnaire has been used widely in research, despite the fact that its estimated internal consistency reliability is not altogether satisfactory. Rotter (1966) reported internal 
reliability coefficients that varied between 0,65 and 0,76 , but explained these as resulting from the wide range of situations tapped by the items (Rotter, 1975). Test-retest reliabilities of 0,83 over one month and 0,49 over two months were also reported (Rotter, 1966).

With respect to convergent validity, Rotter, Seeman and Liverant (1962) reported a statistically significant correlation between the LOC questionnaire and a story completion test measuring external locus of control. The LOC questionnaire was included in the present study, because Antonovsky (1979) and Strümpher (1990) identified LOC as belonging to the salutogenic paradigm. It is noted that the questionnaire is ipsative in nature and contains some of the same items as Kobasa's Personality Hardiness Questionnaire.

\section{Self-efficacy (SE)}

The Self-efficacy Questionnaire developed by Tipton and Worthington (1984) was chosen to measure self-efficacy as defined above. The questionnaire consists of 27 items with a seven-point Likert scale response format. Nine of these items are negatively worded and have to be reverse coded. A high score on the questionnaire indicates a high degree of self-efficacy.

Tipton and Worthington (1984) investigated the construct validity of the Self-efficacy Questionnaire by asking students to record the extent to which they were able to change behaviour of their own choice. The results indicated that students with higher levels of measured self-efficacy were better able to persist with their behaviour modification programmes than students with lower scores on self-efficacy. No reliability information on the questionnaire was obtained.

Both Antonovsky (1987) and Strümpher (1990) included the selfefficacy variable in the salutogenic paradigm. Although the construct 'self-efficacy' was developed in the social-cognitive learning theory framework, it was included among the study variables, because of its expected relation to other salutogenic constructs.

\section{Procedure}

All the measuring instruments were translated into Afrikaans by a panel of three registered psychologists. The original versions and the translations were submitted to a panel of language experts who were then asked for their comments. Where it was indicated, adjustments were made to the translations.

The English and Afrikaans instruments were book-bounded and mailed to the participants who were requested to complete all the instruments and return them within three months. They were assured of anonymity. When the instruments were returned, the data was captured and analysed using the SAS computer package (SAS Institute, 2000).

\section{Data analysis}

This consisted of three steps that were carried out for the two groups separately and a fourth step that used the data obtained on both groups. The first step was to examine the factor structure of the variables included in the study by means of factor analyses. The second step involved estimating the internal consistency reliabilities of the scales/subscales derived by means of the factor analyses and computing the intercorrelations between the scales. In the third step, the factor structure of total scores on the derived scales or subscales were examined in both groups. The fourth step was a confirmatory factor analysis performed on the total sample (White and Other groups combined) to determine whether the variables operationalised in the present study provided an adequate description of the salutogenic construct.

The first step in the analysis of the data was to examine the dimensionality of each of the six measuring instruments separately in order to determine whether a single factor or multiple factors accounted for the variance in the items of each questionnaire. To achieve this goal, exploratory factor analyses (EFAs) were conducted. Thereafter, appropriate sets of items were selected on the basis of the factor analytic results in order to define and compile the set of variables to be used for further study of the salutogenic construct. The factor analyses were done for the White and Other groups separately to allow for the comparison of different population groups (as was argued above under participants).

Maximum-likelihood factor analyses were used throughout and the obtained solutions were rotated using the oblique promax method. The solutions that were based on the standardised regression coefficients offered the clearest interpretation of the factors. The criteria mentioned below guided the number of factors to be extracted:

- Statistical criteria conventionally used, such as Kaiser's eigenvalue-larger-than-one criterion

- The theoretical expectation regarding the number of factors and interpretability of the obtained factors

- Correspondence between the factor solutions of the two groups

- Any given item was considered to belong to a particular factor if it had a factor loading of 0,3 or higher in a particular group, provided that its loading on the same factor for the other group was not less than 0,2 . Theoretical expectations and the contents of factors and items were considered when decisions to include or omit items were not clear-cut.

\section{RESULTS}

\section{Sense of Coherence (SOC)}

The EFA conducted on the SOC questionnaire yielded interpretable single and two-factor structures for both groups. The factor pattern matrices for both solutions and both groups are reported in Table 2. In the table it is indicated to which subscale of the SOC questionnaire (Antonovsky, 1979; 1987) each item belongs. Factor loadings that are equal to or larger than 0,30 are given in the table to facilitate interpretation and comparisons between the groups. Loadings that are smaller than 0,30 are indicated only when a particular item loaded 0,30 or higher on the same factor in the other group.

Items that yielded high loadings in the single factor solution included: 'How often do you have the feeling that there's little meaning in the things you do in your daily life?' (Item 28). 'Do you have very mixed-up feelings and ideas?' (Item 19). 'Doing the things you do every day is a source of deep pleasure satisfaction/a source of pain and boredom' (Item 16). Based on the contents of its high loading items, the factor was labelled as general Sense of Coherence. It was decided to create a new general Sense of Coherence variable to be used in further analyses that included only high loading items on this factor for both groups (All items, except Items 1, 3, 8, 10, 21 , and 28).

The two-factor solution in Table 2 yielded factors that were labelled as Meaningfulness (Factor 1) and Comprehensibility (Factor 2) when the contents of items with high loadings on the two factors were studied. The items of the Manageability subscale were divided between the two factors. The factoranalytic results were used to create two new variables to be used in further analyses named Meaningfulness (Items 11, 7, $22,14,16,27,20,13,4$ and 23) and Comprehensibility (Items $19,17,24,15,12,10,29,26,25,6$ and 5). The three-factor structure that was expected, was not obtained in the present study. Although Frenz et al. (1993) obtained five factors, they recommended that sense of coherence should be studied as a one-dimensional variable. This viewpoint is in line with that of Kravetz, Drory and Florian (1993), McSherry and Holm (1994), Petrie and Brook (1992) and Tartasky (1993). 
TABLE 2

SINGLE FACTOR AND TWO FACTOR SOLUTIONS FOR THE SOC QUESTIONNAIRE: STANDARDISED REGRESSION COEFFICIENTS FOR WHITE AND OTHER GROUPS

\begin{tabular}{|c|c|c|c|c|c|c|c|}
\hline \multirow{3}{*}{ Item } & \multirow{3}{*}{$\begin{array}{l}\text { Expect- } \\
\text { ed }\end{array}$} & \multicolumn{3}{|c|}{ White group $(\mathrm{N}=732)$} & \multicolumn{3}{|c|}{ Other groups $(\mathrm{N}=203)$} \\
\hline & & \multirow[t]{2}{*}{$\begin{array}{l}\text { Single } \\
\text { factor }\end{array}$} & \multicolumn{2}{|c|}{ Two factors } & \multirow[t]{2}{*}{$\begin{array}{l}\text { Single } \\
\text { factors }\end{array}$} & \multicolumn{2}{|c|}{$\begin{array}{l}\text { Two } \\
\text { factor }\end{array}$} \\
\hline & & & 1 & 2 & & 1 & 2 \\
\hline 11 & MEAN & 0,49 & 0,78 & & 0,36 & 0,67 & \\
\hline 7 & MEAN & 0,56 & 0,73 & & 0,42 & 0,68 & \\
\hline 22 & MEAN & 0,56 & 0,71 & & 0,47 & 0,37 & \\
\hline 14 & MEAN & 0,64 & 0,64 & & 0,42 & 0,68 & \\
\hline 16 & MEAN & 0,59 & 0,56 & & 0,33 & 0,49 & \\
\hline 28 & MEAN & 0,69 & 0,55 & & & & \\
\hline 27 & MANA & 0,52 & 0,51 & & 0,51 & 0,72 & \\
\hline 8 & MEAN & 0,62 & 0,52 & & 0,43 & & 0,37 \\
\hline 20 & MANA & 0,52 & 0,5 & & 0,46 & 0,45 & \\
\hline 13 & MANA & 0,49 & 0,48 & & 0,63 & 0,57 & \\
\hline 4 & MANA & 0,45 & 0,4 & & 0,37 & 0,21 & \\
\hline 23 & MANA & 0,31 & 0,37 & & 0,49 & 0,46 & \\
\hline 9 & MANA & 0,52 & 0,31 & & 0,33 & & 0,39 \\
\hline 3 & MEAN & & & & 0,32 & & \\
\hline 19 & COMP & 0,67 & & 0,54 & 0,43 & & \\
\hline & & & & & & 0,49 & \\
\hline 17 & COMP & 0,18 & & 0,59 & 0,48 & 0,41 & \\
\hline 24 & COMP & 0,50 & & 0,55 & 0,44 & 0,46 & \\
\hline 15 & COMP & 0,59 & & 0,54 & 0,37 & 0,64 & \\
\hline 12 & COMP & 0,53 & & 0,53 & 0,66 & 0,45 & \\
\hline 10 & COMP & 0,25 & & 0,51 & 0,18 & 0,60 & \\
\hline 29 & MANA & 0,55 & & 0,50 & 0,38 & & 0,37 \\
\hline 21 & COMP & 0,56 & & 0,49 & & & \\
\hline 26 & COMP & 0,43 & & 0,48 & 0,35 & 0,52 & \\
\hline 25 & MANA & 0,60 & & 0,44 & 0,52 & & 0,53 \\
\hline 6 & MANA & 0,38 & & 0,41 & 0,31 & & 0,32 \\
\hline 5 & COMP & 0,32 & & 0,41 & 0,32 & 0,41 & \\
\hline 18 & MANA & 0,43 & & 0,32 & 0,57 & & \\
\hline 1 & COMP & 0,41 & & & 0,17 & & \\
\hline 2 & MANA & 0,37 & & & 0,33 & & \\
\hline
\end{tabular}

Expected factor: The factor on which the item was expected to load in order to correspond to the subscales conceptualised by Antonovsky (1979).

COMP $=$ Comprehensibility, MEAN $=$ Meaningfulness, MANA $=$ Manageability

\section{Hardiness (HAR)}

The EFA conducted on the Personality Hardiness Questionnaire yielded only single-factor structures that were interpretable for both groups. The factor pattern matrices for both groups are reported in Table 3. In the table it is indicated to which dimension of the PHQ each item belongs as originally conceptualised by Kobasa (1979a; 1979b). An interpretable twofactor solution could not be found for both groups, whereas in the three-factor solution the positively worded items represented one factor and the negatively worded items another factor.

Items that yielded high loadings in the single factor solution included: 'It doesn't matter if you work hard at your job, since only the bosses profit by it anyway' (Item 17). 'Most of the time it just doesn't pay to try hard, since things never turn out right anyway' (Item 19). 'Most people who work for a living are just manipulated by their bosses' (Item 11). 'No matter how hard you work, you never really seem to reach your goals' (Item 14). Based on the contents of its high loading items, the factor was labeled as general Hardiness. It was decided to create a new general Hardiness variable to be used in further analyses that included only items with factor loadings of at least 0.30 on this factor for both groups (Items 17, 19, 14, 11, 7, 13, 45, 32, 8, 29, 50, 16, 31, $44,39,47,48,40,30,43,6,36,46$ and 3$)$.

The results obtained in this study with respect to the Personality Hardiness Questionnaire cannot be regarded as conclusive, because there remain unanswered questions about the hardiness construct as operationalised by the questionnaire. The expected factor pattern has not been found (Funk \& Houston, 1987) and yet some researchers such as Carver, Schreier and Weintraub (1989) recommended that uni-dimensionality cannot be assumed. Proponents of the notion that hardiness should be viewed as a single construct, such as Kobasa et al. (1982) and Wiebe and McCallum (1986), believe that hardiness is the result of the interactive effect of the subscales and that separate scores on hardiness dimensions therefore do not make sense.

TABLE 3

SINGLE FACTOR FOR THE HAR QUESTIONNAIRE: STANDARDISED REgRESSION COEFFICIENTS FOR WHITE AND OTHER GROUPS

\begin{tabular}{|c|c|c|c|}
\hline & & $\begin{array}{l}\text { White group } \\
\quad(\mathrm{N}=732)\end{array}$ & $\begin{array}{l}\text { Other groups } \\
\quad(\mathrm{N}=203)\end{array}$ \\
\hline Item & Expected factor & Single factor & Single factor \\
\hline 17 & Com & 0,56 & 0,54 \\
\hline 19 & Contr & 0,53 & 0,47 \\
\hline 14 & Com & 0,59 & 0,44 \\
\hline 11 & Com & 0,46 & 0,38 \\
\hline 7 & Contr & 0,47 & 0,40 \\
\hline 13 & Contr & 0,39 & 0,33 \\
\hline 45 & Contr & 0,39 & 0,48 \\
\hline 32 & Com & 0,49 & 0,35 \\
\hline 38 & Com & 0,56 & 0,25 \\
\hline 41 & Com & 0,44 & 0,29 \\
\hline 8 & Com & 0,56 & 0,47 \\
\hline 42 & Contr & 0,34 & 0,29 \\
\hline 29 & Com & 0,42 & 0,45 \\
\hline 37 & Chal & & \\
\hline 50 & Com & 0,36 & 0,32 \\
\hline 16 & Contr & 0,36 & 0,42 \\
\hline 31 & Contr & 0,38 & 0,36 \\
\hline 12 & Chal & 0,25 & 0,31 \\
\hline 44 & Com & 0,35 & 0,41 \\
\hline 39 & Com & 0,46 & 0,40 \\
\hline 47 & Com & 0,40 & 0,32 \\
\hline 48 & Contr & 0,34 & 0,37 \\
\hline 10 & Contr & & \\
\hline 40 & Chal & 0,31 & 0,32 \\
\hline 15 & Chal & 0,22 & 0,33 \\
\hline 18 & Chal & & 0,31 \\
\hline 34 & Contr & & 0,31 \\
\hline 20 & Com & 0,23 & 0,36 \\
\hline 35 & Contr & 0,26 & 0,38 \\
\hline 28 & Contr & & \\
\hline 30 & Chal & 0,34 & 0,47 \\
\hline 43 & Chal & 0,40 & 0,40 \\
\hline 6 & Chal & 0,31 & 0,33 \\
\hline 36 & Chal & 0,33 & 0,30 \\
\hline 27 & Chal & & \\
\hline 33 & Chal & & \\
\hline 9 & Chal & 0,31 & 0,24 \\
\hline 49 & Chal & & \\
\hline 23 & Com & 0,48 & 0,24 \\
\hline 1 & Com & 0,35 & 0,21 \\
\hline 22 & Contr & & \\
\hline 46 & Chal & 0,55 & 0,47 \\
\hline 2 & Chal & 0,25 & 0,31 \\
\hline 25 & Contr & & \\
\hline 3 & Contr & 0,37 & 0,33 \\
\hline 24 & Chal & & \\
\hline 4 & Contr & & \\
\hline 5 & Contr & & \\
\hline 26 & Com & & \\
\hline 21 & Chal & & \\
\hline
\end{tabular}

Expected factor: The factor on which the item was expected to load in order to correspond to the subscales conceptualised by Kobasa (1979).

Com $=$ Commitment, Cont $=$ Control, Chal $=$ Challenge

Learned resourcefulness (LR)

The EFA conducted on the SCS yielded interpretable single factor and three-factor solutions for both groups that could be theoretically justified. The factor pattern matrices for both solutions and both groups are reported in Table 4 . 
TABLE 4

SINGLE FACTOR AND THREE-FACTOR SOLUTIONS FOR THE LR QUESTIONNAIRE: STANDARDISED REGRESSION COEFFICIENTS FOR THE WHITE AND OTHER GROUPS

\begin{tabular}{|c|c|c|c|c|c|c|c|c|}
\hline \multirow{3}{*}{ Item } & \multicolumn{4}{|c|}{ White group $(\mathrm{N}=732)$} & \multicolumn{4}{|c|}{ Other groups $(N=203)$} \\
\hline & $\begin{array}{l}\text { Single } \\
\text { factor }\end{array}$ & & $\begin{array}{l}\text { Three } \\
\text { factors }\end{array}$ & & $\begin{array}{l}\text { Single } \\
\text { factor }\end{array}$ & & $\begin{array}{l}\text { Three } \\
\text { factors }\end{array}$ & \\
\hline & & 1 & 2 & 3 & & 1 & 2 & 3 \\
\hline 5 & 0,56 & 0,74 & & & 0,27 & 0,26 & & \\
\hline 15 & 0,52 & 0,61 & & & 0,27 & 0,38 & & \\
\hline 13 & 0,48 & 0,59 & & & 0,26 & 0,48 & & \\
\hline 25 & 0,51 & 0,57 & & & 0,30 & 0,26 & & \\
\hline 17 & 0,53 & 0,56 & & & 0,33 & 0,32 & & \\
\hline 30 & 0,47 & 0,43 & & & 0,35 & & 0,29 & \\
\hline 31 & 0,48 & 0,42 & & & 0,08 & 0,67 & & \\
\hline 20 & 0,46 & 0,41 & & & 0,45 & & 0,38 & \\
\hline 2 & 0,36 & 0,36 & & & 0,56 & & 0,56 & \\
\hline 24 & 0,29 & 0,36 & & & 0,33 & & 0,30 & \\
\hline 1 & 0,35 & 0,36 & & & 0,25 & & 0,23 & \\
\hline 23 & 0,39 & 0,32 & & & 0,09 & 0,56 & & \\
\hline 3 & 0,30 & 0,31 & & & 0,29 & 0,25 & & \\
\hline 34 & 0,50 & & 0,55 & & 0,43 & & 0,42 & \\
\hline 33 & 0,34 & & 0,53 & & 0,6 & & 0,62 & \\
\hline 32 & 0,51 & & 0,53 & & 0,46 & & 0,46 & \\
\hline 22 & 0,48 & & 0,49 & & 0,37 & & 0,42 & \\
\hline 28 & 0,33 & & 0,46 & & 0,30 & & 0,31 & \\
\hline 11 & 0,36 & & 0,45 & & 0,50 & & 0,55 & \\
\hline 7 & 0,50 & & 0,43 & & 0,49 & & 0,48 & \\
\hline 12 & 0,49 & & 0,42 & & 0,56 & & 0,62 & \\
\hline 26 & 0,37 & & 0,38 & & 0,53 & & 0,53 & \\
\hline 10 & 0,48 & & 0,35 & & 0,56 & & 0,53 & \\
\hline 36 & 0,37 & & 0,26 & & 0,06 & 0,40 & & \\
\hline 27 & 0,43 & & 0,24 & & 0,34 & & 0,38 & \\
\hline 35 & $-0,39$ & & & 0,67 & $-0,11$ & & & 0,56 \\
\hline 21 & $-0,28$ & & & 0,60 & 0,23 & & & 0,50 \\
\hline 6 & $-0,29$ & & & 0,53 & 0,10 & & & 0,34 \\
\hline 19 & $-0,26$ & & & 0,51 & $-0,02$ & & & 0,45 \\
\hline 4 & $-0,26$ & & & 0,49 & $-0,02$ & & & 0,46 \\
\hline 18 & $-0,38$ & & & 0,48 & $-0,15$ & & & 0,35 \\
\hline 9 & $-0,34$ & & & 0,46 & $-0,06$ & & & 0,39 \\
\hline 29 & $-0,38$ & & & 0,43 & $-0,06$ & & & 0,35 \\
\hline 14 & $-0,13$ & & & 0,38 & 0,06 & & & 0,40 \\
\hline 16 & $-0,28$ & & & 0,37 & $-0,10$ & & & 0,51 \\
\hline 8 & 0,01 & & & 0,24 & $-0,12$ & & & 0,37 \\
\hline
\end{tabular}

Items that yielded high loadings in the single factor solution included: 'When I find that I have difficulties in concentrating on my reading, I look for ways to increase my concentration' (Item 10). 'When I try to get rid of a bad habit, I first try to find out all the factors that maintain this habit' (Item 12). 'If I find it difficult to concentrate on a certain job, I divide the job into smaller segments' (Item 34). Based on the contents of its high loading items, the factor was labeled as general Learned Resourcefulness. It was decided to create a new general Learned Resourcefulness variable to be used in further analyses that included only high loading items on this factor for both groups (Items 5, 15, 13, 25, $17,30,20,2,24,1,3,34,33,32,22,28,11,7,12,26,10$ and 27).

The three-factor solution in Table 4 yielded factors that were labeled as Control over Negative Emotions (Factor 1), Control over External Demands (Factor 2) and Lack of Control (Factor 3) when the contents of items with high loadings on the three factors were studied.

Items that yielded high loadings on the Control over Negative Emotions factor included: 'When I feel depressed, I try to think of pleasant events' (Item 5). 'When I am depressed, I try to act positively in order to change my mood' (Item 15). 'When an unpleasant thought bothers me, I try to think of something pleasant' (Item 13). These items deal with the control of negative emotions through specific actions. High loading items on the Control over External Demands factor included: 'When I find it difficult to concentrate on a specific task, I divide it into a number of smaller segments' (Item 34). 'When I have a lack of money, I decide to write down all my expenses so that I can plan better for the future' (Item 33). 'When I have much to do, I usually plan my work' (Item 32). The items of Factor 2 deal with solving external demands/problems by means of problem solving skills. Examples of items that yielded high loadings on the third factor, Lack of Control, include: 'I can often not get rid of unpleasant thoughts that worry me' (Item 35). 'Although it makes me feel bad, I cannot help thinking of all possible catastrophes that might happen in the future' (Item 21). 'I cannot help thinking of errors that I made in the past' (Item 6). These items concern the feeling of inability to control internal emotions.

The distinction between control over own emotions and control over external demands, is of importance in the study of reactions to stress. Therefore it was decided to include the three-factor results in further analyses. The factor-analytic results in Table 4 were then used to create three new variables to be used in further analyses. They were named Control over Negative Emotions (Items 5, 15, 13, 25, 17, 31, 23 and 3), Control over External Demands (Items 34, 33, $32,22,28,11,7,12,26,10$ and 27) and Lack of Control (Items 35, $21,6,19,4,18,9,29,14,16$ and 8 ). It should be noted that Factor 3 contains the negatively worded items.

In factor-analytic studies of the SCS it has not been shown that the items cluster according to the themes proposed by Rosenbaum (1980). Redden et al. (1983) obtained six factors, whereas Gruber and Wildman (1987) obtained three factors that correspond with the factors obtained in this study. In a South African study twelve factors were identified for Whites and fourteen for Blacks (Edwards \& Riordan, 1994). However, these results may be questioned, because the questionnaire does not contain enough items to yield as many as twelve or fourteen factors that are adequately determined.

\section{Potency (POT)}

The EFA conducted on the Potency Questionnaire yielded singlefactor structures that were interpretable for both groups. BenSira (1985) did not divide the items of this questionnaire into subscales and therefore it was decided that it would be redundant to explore multiple-factor solutions. The factor pattern matrices for both groups are reported in Table 5 .

TABLE 5

Single factor SOLUTION FOR THE POT QUESTIONNAIRE: STANDARDISED REGRESSION COEFFICIENTS FOR THE WHITE AND OTHER GROUPS

\begin{tabular}{lcc}
\hline & $\begin{array}{c}\text { White group } \\
(\mathbf{N}=\mathbf{7 3 2})\end{array}$ & $\begin{array}{c}\text { Other groups } \\
(\mathbf{N}=203)\end{array}$ \\
\hline Item & Factor loading & Factor loading \\
17 & 0,65 & 0,45 \\
2 & 0,63 & 0,38 \\
18 & 0,59 & 0,45 \\
4 & 0,58 & 0,48 \\
16 & 0,56 & 0,49 \\
14 & 0,55 & 0,29 \\
8 & 0,55 & 0,34 \\
1 & 0,55 & 0,39 \\
7 & 0,54 & 0,35 \\
19 & 0,51 & 0,47 \\
6 & 0,51 & 0,44 \\
12 & 0,48 & 0,34 \\
13 & 0,47 & 0,36 \\
15 & 0,42 & 0,27 \\
11 & 0,41 & 0,35 \\
10 & 0,29 & 0,39 \\
9 & $-0,26$ & $-0,15$ \\
5 & $-0,40$ & $-0,21$ \\
3 & $-0,44$ & $-0,01$ \\
\hline & &
\end{tabular}


Examples of items that yielded high loadings in the single factor solution included: 'Life goals are receding rather than being realised' (Item 17). 'Life is futile' (Item 18). 'I often feel helpless in dealing with the problems of life' (Item 4). Based on the contents of its high loading items, the factor was labeled as Potency. It was decided to create a new general Potency variable to be used in further analyses that included only high loading items on this factor for both groups (All items, except Items 3 and 9).

Internal Locus of Control (LOC)

The EFA conducted on the LOC Questionnaire yielded singlefactor structures that were interpretable for both groups and that fit the theoretical framework as conceptualised by Rotter (1966; 1975 ). The factor pattern matrices for both groups are reported in Table 6.

TABLE 6

SINGLE FACTOR SOLUTION FOR

THE LOC QUESTIONNAIRE: STANDARDISED REGRESSION COEFFICIENTS FOR THE WHITE AND OTHER GROUPS

\begin{tabular}{|c|c|c|}
\hline & $\begin{array}{l}\text { White group } \\
\qquad(\mathrm{N}=732)\end{array}$ & $\begin{array}{l}\text { Other groups } \\
\quad(\mathrm{N}=203)\end{array}$ \\
\hline Item & Factor loading & Factor loading \\
\hline 1 & 0,01 & $-0,06$ \\
\hline 2 & 0,31 & 0,39 \\
\hline 3 & $-0,11$ & $-0,22$ \\
\hline 4 & $-0,29$ & $-0,35$ \\
\hline 5 & $-0,28$ & $-0,06$ \\
\hline 6 & 0,29 & 0,34 \\
\hline 7 & 0,19 & 0,38 \\
\hline 8 & 0,16 & 0,16 \\
\hline 9 & 0,49 & 0,21 \\
\hline 10 & $-0,31$ & $-0,23$ \\
\hline 11 & $-0,52$ & $-0,36$ \\
\hline 12 & $-0,37$ & $-0,28$ \\
\hline 13 & $-0,48$ & $-0,48$ \\
\hline 14 & 0,19 & 0,28 \\
\hline 15 & $-0,41$ & $-0,34$ \\
\hline 16 & 0,33 & 0,40 \\
\hline 17 & 0,47 & 0,49 \\
\hline 18 & 0,55 & 0,38 \\
\hline 19 & $-0,09$ & $-0,16$ \\
\hline 20 & 0,11 & 0,22 \\
\hline 21 & 0,24 & 0,25 \\
\hline 22 & $-0,41$ & $-0,37$ \\
\hline 23 & 0,30 & 0,17 \\
\hline 24 & $-0,04$ & 0,02 \\
\hline 25 & 0,55 & 0,35 \\
\hline 26 & $-0,28$ & $-0,33$ \\
\hline 27 & 0,21 & 0,13 \\
\hline 28 & $-0,45$ & $-0,32$ \\
\hline 29 & 0,34 & 0,29 \\
\hline
\end{tabular}

Examples of items that yielded high loadings in the single factor solution included: 'Many of the unfortunate things that happen to people can be ascribed to bad luck/People's misfortunes are caused by the errors that they make' (Item 2). 'In my case, the attainment of what I want, has little or nothing to do with luck/Often we might as well decide what to do by flipping a coin' (Item 15). The contents of its high loading items indicted that the factor deals with general Locus of Control. It was decided to create a new general Locus of Control variable to be used in further analyses that included only high loading items on this factor for both groups (Items $2,4,6,9,10,11,12,13,15$, $16,17,18,22,25,26,28$ and 29).

\section{Self-efficacy (SE)}

Single-factor and two-factor solutions obtained by means of EFA on the items of the Self-efficacy Questionnaire yielded results that corresponded between the two groups. The factor pattern matrices for both groups and both solutions are reported in Table 7.

TABLE 7

SINGLE FACTOR AND TWO-FACTOR SOLUTIONS FOR THE SE QUESTIONNAIRE: STANDARDISED REGRESSION COEFFICIENTS FOR THE WHITE AND OTHER GROUPS

\begin{tabular}{|c|c|c|c|c|c|c|}
\hline \multirow{3}{*}{ Item } & \multicolumn{3}{|c|}{ White group $(\mathrm{N}=732)$} & \multicolumn{3}{|c|}{ Other groups $(\mathrm{N}=203)$} \\
\hline & \multirow[t]{2}{*}{$\begin{array}{l}\text { Single } \\
\text { factor }\end{array}$} & \multicolumn{2}{|c|}{$\begin{array}{l}\text { Two } \\
\text { factors }\end{array}$} & \multirow[t]{2}{*}{$\begin{array}{l}\text { Single } \\
\text { factor }\end{array}$} & \multicolumn{2}{|c|}{$\begin{array}{l}\text { Two } \\
\text { factors }\end{array}$} \\
\hline & & 1 & 2 & & 1 & 2 \\
\hline 15 & 0,65 & 0,76 & & 0,59 & 0,56 & \\
\hline 14 & 0,63 & $0 ., 72$ & & 0,47 & 0,42 & \\
\hline 4 & 0,59 & 0,69 & & 0,50 & 0,50 & \\
\hline 21 & 0,70 & 0,66 & & 0,67 & 0,72 & \\
\hline 8 & 0,71 & 0,66 & & 0,61 & 0,59 & \\
\hline 20 & 0,66 & 0,66 & & 0,65 & 0,69 & \\
\hline 3 & 0,65 & 0,63 & & 0,67 & 0,67 & \\
\hline 19 & 0,69 & 0,62 & & 0,46 & 0,44 & \\
\hline 18 & 0,53 & 0,60 & & 0,54 & 0,53 & \\
\hline 7 & 0,43 & 0,53 & & 0,53 & 0,54 & \\
\hline 17 & 0,46 & 0,47 & & 0,64 & 0,65 & \\
\hline 6 & 0,60 & 0,46 & & 0,61 & 0,61 & \\
\hline 27 & 0,45 & 0,42 & & 0,36 & 0,36 & \\
\hline 5 & 0,65 & 0,41 & & 0,60 & 0,61 & \\
\hline 13 & 0,36 & 0,39 & & 0,03 & & 0,17 \\
\hline 24 & 0,52 & 0,37 & & 0,54 & 0,52 & \\
\hline 16 & 0,27 & 0,32 & & 0,42 & 0,41 & \\
\hline 23 & 0,20 & 0,24 & & 0,45 & 0,46 & \\
\hline 12 & $-0,46$ & & 0,65 & $-0,39$ & & 0,49 \\
\hline 11 & $-0,41$ & & 0,61 & $-0,35$ & & 0,32 \\
\hline 10 & $-0,33$ & & 0,57 & $-0,09$ & & 0,43 \\
\hline 9 & $-0,35$ & & 0,42 & $-0,08$ & & 0,4 \\
\hline 2 & $-0,35$ & & 0,40 & $-0,19$ & & 0,43 \\
\hline 25 & $-0,10$ & & 0,38 & $-0,01$ & & 0,39 \\
\hline 26 & $-0,19$ & & 0,36 & 0,07 & & 0,23 \\
\hline 1 & $-0,11$ & & 0,31 & 0,24 & 0,25 & \\
\hline 22 & $-0,42$ & & 0,27 & 0,13 & & 0,38 \\
\hline
\end{tabular}

It was decided to disregard the two-factor solution, because Factor 1 consisted of the positively worded items only, whereas the negatively worded items loaded on Factor 2. Examples of items that yielded high loadings in the single factor solution included: 'Nothing is impossible if I really put my mind to it' (Item 15). 'I can succeed in most any endeavour to which I set my mind' (Item 14). 'Once I set my mind to a task almost nothing can stop me' (Item 4).

The contents of its high loading items indicted that the factor deals with a general belief in one's own capability to resolve problems and to cope with life's challenges. The factor was therefore labeled as Self-efficacy. It was decided to create a new general Self-efficacy variable to be used in further analyses that included only high loading items on this factor for both groups (All items, except Items 1, 2, 9, 10, 13, 22, 25 and 26).

The shortened scales and their subscales (in the case of the Sense of Coherence questionnaire and the Self-control Schedule) that were created using EFA, were used as the study variables in the analyses to follow. Negatively worded items were reflected to obtain total scores on the new scales/subscales thus formed and to compute reliability estimates of these scales/subscales.

The second step in the analysis of the data was to compute product-moment correlations between the derived scales and subscales and to obtain the reliabilities of the new scales and subscales. The intercorrelations between these variables are presented in Tables 8 and 9 for the White and Other groups respectively. In the case of the White group, all the 
intercorrelations were statistically significant at the 0,01 level. For the Other groups, the correlations were lower than the corresponding correlations obtained for the White group. Some correlations for the Other group, in particular those involving Control of Negative Emotions, furthermore did not reach statistical significance. Internal consistency reliabilities were subsequently calculated for the each of the derived scales and subscales. The relevant Cronbach alpha coefficients are reported in Table 8 for the White group and in Table 9 for the Other groups. The alpha coefficients are given in brackets in the main diagonal. All the alphas were larger than 0,70 , with the exception of the Control of Negative Emotions and Locus of Control scales for the Other groups.

In the third step of the data analysis, exploratory factor analyses were conducted on the total scores of the derived scales or subscales using the intercorrelations provided in Tables 8 and 9 as the input data. The purpose of these EFAs was to examine the factorial structure of the salutogenic construct that was expected to emerge from these analyses. The Sense of Coherence and the Learned Resourcefulness total scales were omitted from the analyses to prevent artificial overlap between the total scales and their subscales.

The results of these factor analyses for both groups separately are presented in Table 10. In the case of the White group, interpretable single and two-factor solutions were obtained. In the single factor solution, all the scales loaded on the factor that was described as a globalised optimistic life orientation characterised by a strong sense of coherence. In the two-factor solution, the first factor was again interpreted as a global positive orientation, whereas the second factor dealt with specific behavioural skills, including cognitive skills, that are required to control emotional reactions and solve problems. For the Other groups, only a single factor structure could be extracted that met the requirements of Kaiser's rule and the chisquare test. An advantage of maximum-likelihood factor analysis is that a chi-square test is conducted to determine whether the number of factors that were extracted is sufficient for the measurement of a theoretical construct. It is therefore not necessary to rely on the eigenvalue-greater-than-one criterion only. For the Other groups all the scales loaded on the single factor, with the exception of the Control of Negative Emotions and Control over External Demands subscales. As was the case with the White group, the factor was defined by items that were indicative of a global disposition to a positive and optimistic outlook. In the case of the Other groups, the general factor did not include the cognitive and behavioural components measured by the Learned Resourcefulness variable as it did in the case of the White group.

In the fourth and final step of the data analysis a confirmatory factor analysis (CFA), using the Lisrel 8 programme (Jöreskog \& Sorbom, 1993), was conducted to determine the causal structure between the set of derived variables for the total sample, including the White and Other groups, and a latent variable, the salutogenic construct. The assumption was made that the studied variables were significant manifestations of salutogenesis for the total sample. Furthermore, it was assumed that the factorial validation of the variables in both groups provided enough

TABLE 8

INTERCORRELATION BETWEEN THE DERIVED SCALES AND SUBSCALES FOR THE WHITE GROUP $(\mathbf{N}=732)$

\begin{tabular}{|c|c|c|c|c|c|c|c|c|c|c|c|}
\hline Derived scales/subscales & 1 & 2 & 3 & 4 & 5 & 6 & 7 & 8 & 9 & 10 & 11 \\
\hline 1. Sense of Coherence & $(0,88)$ & & & & & & & & & & \\
\hline 2. Meaningfulness & 0,83 & $(0,82)$ & & & & & & & & & \\
\hline 3. Comprehensibility & 0,84 & 0,45 & $(0,82)$ & & & & & & & & \\
\hline 4. Hardiness & 0,52 & 0,53 & 0,33 & $(0,82)$ & & & & & & & \\
\hline 5. Potency & 0,66 & 0,63 & 0,49 & 0,57 & $(0,85)$ & & & & & & \\
\hline 6. Learned Resourcefulness & 0,45 & 0,43 & 0,35 & 0,19 & 0,35 & $(0,86)$ & & & & & \\
\hline 7. Control over Negative Emotions & 0,38 & 0,38 & 0,25 & 0,21 & 0,27 & 0,75 & $(0,77)$ & & & & \\
\hline 8. Control over External Demands & 0,37 & 0,33 & 0,33 & 0,12 & 0,28 & 0,87 & 0,46 & $(0,78)$ & & & \\
\hline 9. Lack of Control & 0,57 & 0,45 & 0,50 & 0,39 & 0,51 & 0,30 & 0,26 & 0,29 & $(0,75)$ & & \\
\hline 10. Locus of Control & 0,53 & 0,45 & 0,46 & 0,41 & 0,64 & 0,35 & 0,24 & 0,33 & 0,36 & $(0,76)$ & \\
\hline 11. Self-efficacy & 0,53 & 0,55 & 0,37 & 0,32 & 0,32 & 0,48 & 0,42 & 0,40 & 0,42 & 0,37 & $(0,87)$ \\
\hline
\end{tabular}

Note: All the correlations are statistically significant at the 0,01 level.

Cronbach alpha coefficients are given in brackets along the main diagonal.

TABLE 9

INTERCORRELATION BETWEEN THE DERIVED SCALES AND SUBSCALES FOR OTHER GROUPS $(\mathbf{N}=732)$

\begin{tabular}{|c|c|c|c|c|c|c|c|c|c|c|c|}
\hline Derived scales/subscales & 1 & 2 & 3 & 4 & 5 & 6 & 7 & 8 & 9 & 10 & 11 \\
\hline 1. Sense of Coherence & $(0,83)$ & & & & & & & & & & \\
\hline 2. Meaningfulness & $0,82 * *$ & $(0,79)$ & & & & & & & & & \\
\hline 3. Comprehensibility & 0,80 ** & 0,37 ** & $(0,77)$ & & & & & & & & \\
\hline 4. Hardiness & $0,46^{* *}$ & $0,36^{* *}$ & $0,38^{* *}$ & $(0,78)$ & & & & & & & \\
\hline 5. Potency & $0,57 * *$ & $0,48^{* *}$ & $0,46^{* *}$ & $0,60 * *$ & $(0,74)$ & & & & & & \\
\hline 6. Learned Resourcefulness & 0,21 * * & 0,17 * & 0,19 ** & 0,13 & 0,13 & $(0,81)$ & & & & & \\
\hline 7. Control over Negative Emotions & 0,10 & 0,05 & 0,11 & 0,13 & 0,09 & 0,52 ** & $(0,64)$ & & & & \\
\hline 8. Control over External Demands & $0,18 * *$ & $0,15^{*}$ & $0,15^{*}$ & 0,12 & 0,09 & 0,87 * * & 0,21 ** & $(0,77)$ & & & \\
\hline 9. Lack of Control & $0,44^{* *}$ & 0,40 ** & 0,40 ** & 0,34 * * & 0,44 ** & 0,01 & 0,00 & 0,05 & $(0,71)$ & & \\
\hline 10. Locus of Control & $0,39 * *$ & 0,32 ** & 0,37 ** & 0,40 ** & $0,42 * *$ & 0,22 ** & $0,15^{*}$ & 0,22 ** & 0,34 * * & $(0,69)$ & \\
\hline 11. Self-efficacy & $0,29 * *$ & 0,27 ** & 0,21 * * & $0,22 * *$ & 0,26 ** & 0,30 ** & 0,22 ** & 0,23 ** & 0,17 * & 0,41 * * & $(0,86)$ \\
\hline
\end{tabular}

Note: Cronbach alpha coefficients are given in brackets along the main diagonal.

** Statistically significant at the 0,01 level.

* Statistically significant at the 0,05 level. 
grounds to lump the data for the two groups together. The input data for the confirmatory factor analysis was an intercorrelation matrix of the derived scales based on the results for the combined sample. The results are reported in Table 11.

TABLE 10

OBLIQUELY ROTATED FACTOR PATTERN MATRICES OF THE TOTAL SCORES ON THE DERIVED SCALES OR SUBSCALES: STANDARDISED REGRESSION COEFFICIENTS FOR THE WHITE AND OTHER GROUPS

\begin{tabular}{lcccc}
\hline & \multicolumn{2}{c}{ White group } & Other groups \\
\hline Derived scales/subscales & $\begin{array}{l}\text { Single } \\
\text { factor }\end{array}$ & Factor 1 & Factor 2 & $\begin{array}{c}\text { Single } \\
\text { factor }\end{array}$ \\
\hline Potency & 0,83 & 0,88 & 0,77 \\
Hardiness & 0,62 & 0,70 & & 0,66 \\
Locus of Control & 0,67 & 0,62 & & 0,61 \\
Meaningfulness & 0,77 & 0,56 & & 0,55 \\
Lack of Control & 0,62 & 0,46 & & 0,56 \\
Comprehensibility & 0,62 & 0,43 & & 0,61 \\
Control over External Demands & 0,44 & & 0,74 & \\
Control over Negative Emotions & 0,43 & & 0,71 & \\
Self-efficacy & 0,64 & & 0,52 & 0,45 \\
\hline
\end{tabular}

Factor loadings smaller than 0,30 are omitted

TABLE 11

CONFIRMATORY FACTOR ANALYSIS RESULTS FOR THE COMBINED SAMPLE $(\mathbf{N}=935)$

\begin{tabular}{lccc}
\hline Derived scales/subscales & $\begin{array}{c}\text { Parameter } \\
\text { estimate }\end{array}$ & $\begin{array}{c}\text { 1-R } \\
\text { variance }\end{array}$ & $\begin{array}{c}\mathbf{R}^{2} \text { : True } \\
\text { variance }\end{array}$ \\
\hline Sense of Coherence & $0,99^{*}$ & 0,02 & 0,98 \\
Meaningfulness & $0,83^{*}$ & 0,32 & 0,68 \\
Comprehensibility & $0,83^{*}$ & 0,32 & 0,68 \\
Hardiness & $0,52^{*}$ & 0,73 & 0,27 \\
Potency & $0,61^{*}$ & 0,63 & 0,37 \\
Learned Resourcefulness & $0,41^{*}$ & 0,83 & 0,17 \\
Control over Negative Emotions & $0,33^{*}$ & 0,89 & 0,11 \\
Control over External Demands & $0,34^{*}$ & 0,88 & 0,12 \\
Lack of Control & $0,55^{*}$ & 0,70 & 0,30 \\
Locus of Control & $0,52^{*}$ & 0,73 & 0,27 \\
Self-efficacy & $0,49^{*}$ & 0,76 & 0,24 \\
\hline
\end{tabular}

* Statistically significant at the 0,01 level

In Table 11 it is indicated that all the derived scales and subscales are statistically significant manifestations of salutogenesis $(\mathrm{p}<0,01)$. However, a weak fit was obtained, because the RMSEA was equal to 0,22 , thereby not meeting the value of 0,05 that Jöreskog and Sorbom (1993) suggested is indicative of a good fit.

\section{DISCUSSION}

\section{Conclusion}

The expected factor structures for these six salutogenic constructs (as measured by the chosen instruments), were not found in this research. It was concluded that the constructs as operationalised by these instruments need further refinement towards reflecting its conceptualisation clearly. For each construct, there was enough similarity between the White and Other groups, to warrant further investigation.

All the measuring instruments used showed acceptable internal consistency reliability.
The analysis of the factor structure for the White and Other groups separately, indicated the following:

- Sense of coherence, for both groups, manifested as meaningfulness and comprehensibility in two different factors. Manageability was found to be a separate factor, but loading on both the other two factors. This finding was incongruent to the conceptualisation offered by Antonovsky (1984a; 1987).

- Hardiness, for both groups, manifested as one factor including commitment, control and challenge. This finding was incongruent to the conceptualisation offered by Kobasa (1982).

- Learned resourcefulness, for the White group, showed questionable results and for the Other group did not contribute towards the conceptualisation. This finding was incongruent to the conceptualisation by Rosenbaum (1980).

- Potency, for both groups, manifested in a single factor. This finding was congruent to the conceptualisation by Ben-Sira (1985; 1989).

- Internal locus of control, for both groups, manifested in a single factor. This finding was congruent to the conceptualisation by Rotter (1966).

- Self-efficacy, for both groups, manifested in a single factor. This finding was congruent to the conceptualisation by Bandura (1997).

- Sense of coherence, potency, internal locus of control and self-efficacy contributed to the overall description of salutogenic functioning, hardiness contributed very little and learned resourcefulness did not contribute.

Factor analysis showed the following factors manifesting for the two groups:

- For the White group, salutogenic functioning consisted of a general factor, with a second and possibly a third factor. The first factor referred to an optimistic view of life and a realistic involvement; external demands are seen as challenges and therefor worthwhile; a willingness to get involved in the external environment; effective stress management and good health. The second factor referred to behavioural skills facilitating stress management on a practical level; these skills facilitate the effective handling of negative emotions during stress as well as endurance in this endeavour. The possible third factor referred to the perception that resources are available; the skill to comprehend environmental stimuli; the availability of resources influences the individual's internal power; the understanding of and about environmental stimuli leads to the investigation of options for behaviour; the availability of resources enhances the individual's perception of control and power.

- For the Other group, salutogenic functioning consisted of one factor. This referred to an optimistic view of life; experiencing environmental stimuli as understandable and meaningful; an active involvement in own world.

There appears to be little known about the unique manifestation and operationalisation of salutogenic functioning amongst different cultural groups. Although this research indicated a mutual salutogenic functioning behaviour amongst Whites and Others, namely an optimistic view of life and the experience of life situations as meaningful, there seems to be more difference between the groups than similarities. It is concluded that salutogenic functioning manifests differently between the different cultural and language groups in South Africa.

Confirmatory factor analysis showed a weak fit between the conceptualisation of salutogenic functioning, and the present operationalisation of these six constructs. It was concluded that the salutogenic functioning as part of the positive psychology paradigm, is not yet sufficiently clear and that there exists an incongruency between the conceptualisation and its operationalisation. 


\section{Recommendations}

Research within industrial and organisational psychology should continue to explore the factor structure of and relationships between the above salutogenic functioning constructs, as well as the newer constructs within positive psychology (as mentioned in the introduction above). Attention should be given to clarity in the theoretical description of the constructs as well as the compilation of its measuring instruments. Especially, (1) the research should be performed within an overall personality theory, and (2) the effect of negative affectivity should be investigated and controlled. Perhaps the relatively new positive psychology could facilitate such an integrative view on personality and the construct positive affect (Folkman \& Moskowitz, 2000) could be used to understand the role of negative affect. Future research should include the diversity in the South African population to establish the differences in experiences more clearly, as well as between the different organisational levels and professional groups.

Because this research was performed at a time of major changes in South Africa, it is recommended that this study is repeated to establish whether the ever developing social, political and economic scenario affects the nature of salutogenic functioning amongst South Africa's diverse population groups.

\section{REFERENCES}

Antonovsky, A. (1979). Health, stress and coping: New perspectives on mental and physical wellbeing. San Francisco: Jossey-Bass.

Antonovsky, A. (1984a). A call for a new question - salutogenesis - and a proposed answer - the sense of coherence. Journal of Preventive Psychiatry, 22 (1), 1-11.

Antonovsky, A. (1984b). The sense of coherence as a determinant of health. In J.D. Matarazzo, S.M. Weiss, J.A. Herd, M.E. Miller \& S.M. Weiss (Eds.). Behavioral health: A handbook of health enhancement and disease prevention, 114-129. New York: Wiley.

Antonovsky, A. (1987). Unravelling the mystery of health: How people manage stress and stay well. San Franscisco: Jossey-Bass.

Antonovsky, A. (1991). The structural sources of salutogenic strengths. In C.L. Cooper \& R. Payne (Eds.). Personality and stress. Individual differences in the stress process, 67-104. Chichester: Wiley.

Antonovsky, A. (1993a). Complexity, conflict, chaos, coherence and civility. Social Science and Medicine, 37(8), 969-974.

Antonovsky, A. (1993b). The structure and properties of the sense of coherence scale. Social science and medicine, 36 (6), 725733.

Antonovsky, A. \& Sagy, S. (1990). Confronting developmental tasks in the retirement transition. Gerontology, 30, 362-368.

Aspinwall, L.G. \& Staudinger, U.M. (2003). A psychology of human strengths. Fundamental questions and future directions for a positive psychology. Washington: APA.

Bandura, A. (1977). Social learning theory. Englewood Cliffs: Prentice-Hall.

Bandura, A. (1982). Self-efficacy mechanisms in human agency. American Psychologist, 37, 122-147.

Bandura, A. (1989). Human agency in social cognitive theory. American Psychologist, 44 (9), 1175-1184.

Bandura, A. (1997). Self-efficacy: The exercise of control. New York: Freeman.

Barling, J. \& Beattie, R. (1983). Self-efficacy beliefs and sales performance. Journal of Organizational Behavior Management, $5,41-51$.

Barnard, N. (2001). Die verwantskap tussen stres en persoonlikheidsweerstandsbronne by bestuurders tydens transformasie. Masters dissertation. University of South Africa, Pretoria.

Basson, M. \& Rothmann, S. (2001). Sense of coherence, coping and burnout of pharmacists. Paper presented at the Annual Conference of the Society of Industrial Psychology, Pretoria.
Ben-Sira, Z. (1985). Potency: A stress-buffering link in the coping-stress-disease relationship. Social Sciences and Medicine, 21 (4), 397-406.

Ben-Sira, Z. (1989). Potency: A readjustment-promoting link in the rehabilitation of disabled persons. Sociology of Health and Illness, 11 (1), 41-61.

Bernstein, J. \& Carmel, S. (1987). Trait anxiety and the sense of coherence. Psychological Reports, 60, 1000.

Boyle, A., Grap, M.J., Younger, J. \& Thornby, D. (1991). Personality hardiness, ways of coping, social support and burnout in critical care nurses. Journal of Advanced Nursing 16 (7), 850-857.

Breed, M. (1997). Bepalende persoonlikheidskenmerke in die salutogeniese paradigma. Doctoral thesis. University of South Africa, Pretoria.

Brooks, J.D. (1992). A salutogenic theory of successful aging. Doctoral thesis. Perdue University, Perdue.

Campbell, J.M., Amerikaner, M., Swank, P. \& Vincent, K. (1989). The relationship between the hardiness test and the personal orientation inventory. Journal of Research in Personality, 23 (3), 313-380.

Carr, A. (2004). Positive Psychology: The science of happiness and human strengths. London: Bruner-Routledge.

Carver, C.S., Schreier, M.F. \& Weintraub, J.K. (1989). Assessing coping strategies: A theoretically based approach. Journal of Personality and Social Psychology, 56, 577-585

Cilliers, F. (2001.) The role of sense of coherence in group relations training. Journal of Industrial Psychology, 27 (3), 13-18.

Cilliers, F. (2002). Salutogenic coping with burnout among nurses: a qualitative study. SA Journal of Labour Relations, 26 (4), 61-85.

Cilliers, F. \& Coetzee, S.C. (2003). The theoretical-empirical fit between three psychological wellness constructs: Sense of coherence, learned resourcefulness and self-actualisation. South African Journal of Labour Relations, 27 (1), 4-24.

Cilliers, F. \& Kossuth, S. (2002). The relationship between organisational climate and salutogenic functioning. Journal of Industrial Psychology, 28 (1), 8-13.

Cilliers, F. \& Kossuth, S.P. (2004). The reliability and factor structure of three measures of salutogenic functioning. $S A$ Journal of Labour Relations, 28 (2), 59-76.

Cilliers, F., Viviers, A.M. \& Marais C.P. (1998). Salutogenesis: a model to understand coping with change. Unisa Psychologia, 25 (2), 32-39.

Coetzee, S.C \& Cilliers, F. (2001). Psychofortology: Explaining coping behaviour in organisations. The IndustrialOrganisational Psychologist, 38 (4), 62-68.

Dahlin, L., Cederblad, M., Antonovsky, A. \& Hagnell, O. (1990). Childhood vulnerability and adult invincibility. Acta Psychiatry Scandinavia, 82, 228-232.

Danana, D. (1989). Relationships between stressors and outcomes amongst nurses. Unpublished Report. Department of Psychology, University of Cape Town.

Diener, E. (2000). Subjective well-being. the science of happiness and a proposal for a national index. American Psychologist, 55 (1), 34-43.

Edwards, D. \& Riordan, S. (1994). Learned resourcefulness in black and white South African University students. The Journal of Social Psychology, 134, 665-675.

Erwee, R. \& Pottas, C.D. (1982). Locus of control and achievement motivation of managers. Psychologica Africana, 21, 79-102.

Feltz, D.L. (1982). Path analysis of the casual elements in Bandura's theory of self-efficacy and an anxiety-based model of avoidance behavior. Journal of Personality and Social Psychology, 42, 764-781.

Flannery, R.B., Perry, C., Penk, W.E. \& Flannery, G.J. (1994). Validating Antonovsky's sense of coherence scale. Journal of Clinical Psychology, 50, 575-577.

Foley, J.R. \& Clifton, R.A. (1990). Locus of control, organisational climate, and participation in staff development: a study of college students. The Canadian Journal of Higher Education, 20 (2), 45-59. 
Folkman, S. \& Moskowitz, J.T. (2000). Positive affect and the other side of coping. American Psycholopgist, 55 (6):647-654.

Fouché, E. (1999). Takbestuurders in Senwes Beperk se coping met veradeing: ' $n$ Fortigene benadering. Masters dissertation. Potchefstroom University for CHE, Potchefstroom.

Fredrickson, B.L. (2001). The role of positive emotions in positive psychology. American Psychologist, 56 (3), 218-226.

Frenz, A.W. (1990). Measuring Antonovsky's sense of coherence construct: A psychometric study. Dissertation Abstracts International, 51, 6141.

Frenz, A.W., Carey, M.P. \& Jorgensen, R.S. (1993). Psychometric evaluation of Antonovsky's sense of coherence scale. Psychological Assessment, 5, 145-153.

Funk, S.C. (1992). Hardiness: A review of theory and research. Health Psychology, 11 (5), 335-345.

Funk, S.C. \& Houston, B.K. (1987). A critical analysis of the hardiness scale's validity and utility. Journal of Personality and Social Psychology, 53, 572-578.

Garson, B.E. \& Stanwyck, D.J. (1997). Locus of control and incentive in self managing teams. Human Resource Development Quarterly, 8 (3), 247-258.

Gist, M.E. \& Mitchell, T.R. (1992). Self Efficacy: A theoretical analysis of its determinants and malleability. Academy of Management Review, 17 (2), 183-211.

Gruber, V.A. \& Wildman, B.G. (1987). The impact of dysmenorrhea on daily activities. Behaviour Research and Therapy, 25, 123-128.

Hackett, G. \& Betz, N.E. (1981). A self-efficacy approach to the career development of women. Journal of Vocational Behaviour, 18, 326-339.

Jackson, T.L.B. (2004). Burnout and engagement of teachers in the North West Province. Doctoral Thesis. North West University, Potchefstroom.

Johnson, G.A. (1993). Sense of coherence, perceived health and the performance of health-promoting behaviours. Doctoral thesis. Boston College, Boston.

Jones, R.A. (1996). Research methods in the social and behavioural sciences. Sunderland: Sinauer.

Jöreskog, K.G. \& Sorbom, D. (1993). Windows LISREL 8.10. Chicago: Scientific Software International.

Kalimo, R. \& Vuori, J. (1990). Work and sesne of coherence resources for competence and life satisfaction. Behavioural Medicine, 16, 76-89.

Keyes, C.L.M. \& Haidt, J. (2003). Flourishing. Positive psychology and the life well lived. Washington: APA.

Kirsch, I. (1986). Early research on self-efficacy: What we already know without knowing we knew. Journal of Social and Clinical Psychology, 4 (3), 339-358.

Kobasa, S.C. (1979a). Personality and resistance to illness. American Journal of Community Psychology, 7 (4), 413-423.

Kobasa, S.C. (1979b). Stressful life events, personality, and health: An inquiry into hardiness. Journal of Personality and Social Psychology, 37 (1), 1-11.

Kobasa, S.C. (1982). The Hardy Personality: Toward a social psychology of stress and health. In G.S. Sanders \& J.Suls (eds.). The Social Psychology of Health and Illness. Hillside: Lawrence Erlbaum.

Kobasa, S.C., Maddi, S.R. \& Kahn, S. (1982). Hardiness and health: A prospective study. Journal of Personality and Social Psychology, 42, 168-177.

Kobasa, S.C., Maddi, S.R., Pucetti, M.C. \& Zola, M.A. (1985). Effectiveness of hardiness, exercise and support as resources against illness. Journal of Psychosomatic Research, 29 (5), 52533.

Kobasa, S.C., Maddi, S.R. \& Zola, M.A. (1985). Type A and hardiness. Journal of Behavioural Medicine, 6 (1), 41-51.

Kobasa, S.C. \& Puccetti, M.C. (1983). Personality and social resources in stress resistance. Journal of Personality and Social Psychology, 45 (4), 839-850.

Kossuth, S.P. (1998). Team building and salutogenic orientations contextualised in a performance model. Doctoral thesis. University of South Africa, Pretoria.
Kossuth, S.P. \& Cilliers, F. (2002). The relationship between leadership dimensions, cultural beliefs and salutogenic functioning. SA Journal of Labour Relations, 26 (1), 65-95.

Kravetz, S., Drory, Y. \& Florian, V. (1993). Hardiness and sense of coherence and their relation to negative affectivity. European Journal of Personality, 7, 233-244.

Lambert, C.E. \& Lambert, V.A. (1987). Hardiness: Its development and relevance to nursing. Image: Journal of Nursing Scholarship, 19 (2), 92-95.

Lee, C. (1988). The effects of goal setting and monetary incentives on self-efficacy and performance. Journal of Business and Psychology, 2 (4), 366-372.

Lefcourt, H.M. (1982). Locus of control: Current trends in the theory and research. Hillsdale: Lawrence Erlbaum.

Linley, P.A. \& Joseph, S. (2004). Positive psychology in practice. New York: John Wiley.

Lochner, H.D. (2000). Die verband tussen psigologiese kragte en werkstevredenheid van werknemers in ' $n$ vervaardigingsbedryf. Masters dissertation. Potchefstroom University for $\mathrm{CHE}$ Potchefstroom.

Lopez, S.J. \& Snyder, C.R. (2003). Positive psychology assessment. A handbook of models and measures. Washington: APA.

Lyubomirsky, S. (2001). Why are some people happier than others? The role of cognitive and motivational processes in well-being. American Psychologist, 45 (3), 239-249.

Masten, A.S. (2001). Ordinary magic. resilience processes in development. American Psychologist, 56 (3), 227-238.

McSherry, W.C. \& Holm, J.E. (1994). Sense of coherence: Its effects on psychological and physiological processes prior to, during and after a stressful situation. Journal of Clinical Psychology, 50, 476-487.

Motshele, V.M. (2001). The relationship between salutogenic functioning and sick leave. Masters dissertation. University of South Africa, Pretoria.

Nakamura, J. \& Csikszentmihalyi, M. (2001). Catalytic creativity. American Psychologist, 56 (4):337-341.

Naudé, J.J.P. (1999). Psychological strengths and job satisfaction of representatives in the fertiliser industry. Doctoral thesis. Potchefstroom University for CHE, Potchefstroom.

Parkes, K.R. \& Rendall, D. (1988). The hardy personality and its relationship to extraversion and neuroticism. Personality and Individual Differences, 9, 785-790.

Payne, D.D. \& Manning, B.H. (1988). The effect of cognitive selfinstructional strategies on preservice teachers' locus of control. Journal of Contemporary Educational Psychology, 13, 140-145.

Peterson, C. (2000). The future of optimism. American Psychologist, 55 (1), 44-55.

Petrie, K. \& Brook, R. (1992). Sense of coherence, self-esteem, depression and hopelessness as correlates of reattempting suicide. British Journal of Clinical Psychology, 31, 293-300.

Redden, E.M., Tucker, R.K. \& Young, L. (1983). Psychometric properties of the Rosenbaum schedule for assessing selfcontrol. Psychological Record, 33, 77-86.

Rosenbaum, M. (1980). A schedule for assessing self-control behaviors: preliminary findings. Behavior Therapy, 11, 109121.

Rosenbaum, M. (1990). Learned resourcefulness: On coping skills, self-control and adaptive bahavior. New York: Springer

Rosenbaum, M. (1989). Self-control under stress: the role of learned resourcefulness. Advances in Research and Therapy, 11 (4), 249-258.

Rosenbaum, M. \& Ben-Ari, K. (1985). Learned helplessness and learned resourcefulness: Effects of non-continent success and failure on individuals differing in self-control skills. Journal of Personality and Social Psychology, 48 (1), 198-215.

Rosenbaum, M. \& Jaffe, Y. (1983). Learned helplessness: the role of the individual differences in learned resourcefulness. British Journal of Social Psychology, 22, 215-225.

Rosenbaum, M. \& Palmon, N. (1984). Helplessness and resourcefulness in coping with epilepsy. Journal of Consulting and Clinical Psychology, 52 (2), 244-253. 
Rothmann, S. (2002). Burnout and engagement: A fortogenic perspective. Inaugural lecture, Potchefstroom University, November.

Rotter, J.B. (1966). Generalised expectations for internal versus external control of reinforcements. Psychological Monographs, $80,1-67$.

Rotter, J.B. (1975). Some problems and misconceptions related to the construct of internal versus external control of reinforcement. Journal of Consulting and Clinical Psychology, 43, 56-67.

Rotter, J.B., Seeman, M. \& Liverant, S. (1962). Internal vs external locus of control of reinforcement: A major variable in behavior therapy. In N.F. Washburne, Decisions, values and groups (p. 473-516). London: Pergamon.

SAS Institute. (2000). The SAS System for Window's: Release 8.01. Cary, NC: SAS Institute Inc.

Schneider, S.L.( 2001). In search of realistic optimism. American Psychologist, 56 (3), 250-263.

Seligman, M.E.P. (2003). Authentic happiness. Using the new positive psychology to realize your potential for lasting fulfilment. London: Nicholas Brealey.

Seligman, M.E.P. \& Csikszentmihalyi, M. (2000). Positive psychology. American Psychologist, 55 (1), 5-14.

Sheldon, K.M. \& King, L. (2001). Why positive psychology is necessary. American Psychologist, 56 (3), 216-217.

Simonton, D.K. (2000). Creativity: cognitive, personal, development and social aspects. American Psychologist, 55 (1), 151-158.

Snyder, C.R. \& Lopez, S.J. (2002). Handbook of positive psychology. Oxford: Oxford.

Somerfield, M.R. \& McCrae, R.R. (2000). Stress and coping research. American Psychologist, 55, (6), 620-625.

Storm, K. (2002). Burnout and workengagement in the South African Police Services. Doctoral thesis. Potchefstroom University for CHE, Potchefstroom.

Strümpfer, D.J.W. (1990). Salutogenesis: A new paradigm. South African Journal of Psychology, 20 (4), 264-276.

Strdmpfer, D.J.W. (1995). The origins of health and strength: From "salutogenesis to fortigenesis". Psychology, 25 (2), 8189.

Strümpfer, D.J.W. (1998). Sense of coherence and job satisfaction: Review of South African data. Paper presented at the National Congress of the Psychology Society of South Africa, Cape Town.

Strümpfer, D.J.W. \& Wissing, M.P. (1998). Review of South African data on the sense of coherence scale as a measure of fortigenesis and salutogenesis. Paper presented at the National Congress of the Psychology Society of South Africa, Durban.
Tartasky, D.S. (1993). Hardiness: Conceptual and methodological issues. Journal of Nursing Scholarship, 25, 225-229.

Taylor, M.S., Locke, E.A., Lee, C. \& Gist, M.E. (1984). Type A behaviour and faculty research productivity: what are the mechanisms? Journal of Organisational Behaviour and Human Performance, 34, 402-418.

Tipton, R.M. \& Worthington, E.L. (1984). The measurement of generalized self-efficacy: A study of construct validity. Journal of Personality Assessment, 48, 545-548.

Viviers, A.M. (1996). Salutogenese in organisatoriese konteks. Doctoral thesis. University of South Africa, Pretoria.

Viviers, A.M. (1999). Die persoonlikheidsoriëntasieprofiel van die salutogenies-funksionerende mens. Journal of Industrial Psychology, 25 (1), 21-26.

Viviers, A.M. \& Cilliers, F. (1999). Die verband tussen salutogenese en werkoriëntasie. Jounal of Industrial Psychology, 25 (1), 27-32.

Wiebe, D.J. \& McCallum, D.M. (1986). Health practices and hardiness as mediators in the stress-illness relationship. Health Psychology, 5, 425-438.

Wiebe, D.J. \& Williams, P.G. (1992). Hardiness and health: A special psycho-physiological perspective on stress and adaptation. Journal of Social and Clinical Psychology, 11, 238-262.

Williams, P.G., Wiebe, D.J. \& Smith, T.W. (1992). Coping processes as mediators of the relationship between hardiness and health. Journal of Behavioural Medicine, 15, 237-255.

Wissing, M.P. (2000). Wellness: Construct clarification and a framework for future research and practice. Paper presented at the First South African Wellness Conference, Port Elizabeth.

Wissing, M.P. \& Van Eeden, C. (1994). Psychological well being: Measurement and construct clarification. Paper presented at the 23rd International Congress of Applied Psychology, Madrid.

Wissing, M.P. \& Van Eeden, C. (1997a). Facing the challenge to explicate mental health salutogenically: Sense of coherence and psychological well-being. Paper presented at the 55th Annual Convention of the International Council of Psychology, Graz.

Wissing, M.P. \& Van Eeden, C. (1997b). Psychological well-being: A fortigenic conceptualisation and empirical clarification. Paper presented at the PsySSA National Congress, Durban.

Wissing, M.P. \& Van Eeden, E. (2002). Empirical clarification of the nature of psychological well-being. SA Journal of Psychology, 32 (1), 32-44.

Wood, R. \& Bandura, A. (1989). Social cognitive theory of organisational management. Academy of Management Review, 14 (3), 36. 
REVIEW PANEL EDITION 32.1 (2006)

Prof Coen Bester

Prof AB Boshoff

Mr Gawie Cilliers

Dr Melinde Coetzee

Ms Anne Crafford

Ms R van Eeden

Prof JJD Havenga

Prof Tina Kotze

Mr Ian Liebenberg

Dr Annetjie Moore

Dr Karina Mostert

Dr Wikus Naude

Prof HJ Pietersen

Dr P Schaap

Prof W Schurink

Mr Marius Stander

Mr EJ Steyn
University of the Free State

North-West University

University of Stellenbosch

UNISA

University of Johannesburg

UNISA

North-West University

University of the Free State

UNISA

NAS Treasury

North-West University

North-West University

University of Limpopo

University of Pretoria

University of Johannesburg

North-West University

University of Pretoria 